\title{
Using Directive Feedback to Improve Students' Writing Skills: A Case Study of English Department Students
}

\author{
Rina Febrina Sarie \\ Faculty of Education \\ Universitas Siswa Bangsa Internasional \\ E-mail: Rina.sarie@sampoernaeducation.net
}

Doi:10.7575/aiac.alls.v.4n.2p.74

URL: http://dx.doi.org/10.7575/aiac.alls.v.4n.2p.74
Received: 03/04/2013

Accepted: 03/06/2013

\begin{abstract}
Directive feedback is one of strategy to check students' grammatical error in writing. This strategy is used by the lecturer in PETA (Principle of Effective Teaching and Assessment) course during third semester. This research used case study to investigate whether directive feedback could improve students' writing skill. Besides that, it also tried to explore the commonest grammatical error in student's writing and students' feeling toward directive feedback. The participants of this research were students of Universitas Siswa Bangsa Internasional, who took PETA course. The data was gained from record observation and students' interview. Record observation was obtained from students' ereflection during PETA course. The result was directive feedbacks could improve students' writing skill with one condition. That is students should be aware of the feedbacks given by the lecturer and learn it. The conclusion opens possibility for further research to find the level of effectiveness of directive feedback in improving students' writing skill and the level of students' writing skill improvement.
\end{abstract}

Keywords: Directive feedback, writing skill, e-reflection.

\section{Background}

Feedback used in educational contexts is generally regarded as a crucial to improving knowledge and skill acquisition (Epstein et al., 2002; Moreno, 2004). Therefore, the type of feedback and its effectiveness for improving writing skill has been the focus of significant research. In addition to its influence on achievement, feedback is also depicted as a significant factor in motivating learning (e.g., Lepper \& Chabay, 1985; Narciss \& Huth, 2004). However, students may sometimes feel frustrated and confused while reading their teacher's suggestion and comments. It is the role of teacher to state clearly what part of an essay need improvement, and what specific linguistic errors that students have to improve.

Therefore, giving directive feedback is used by one of the lecturer in PETA (Principle of Effective Teaching and Assessment) course for English Department students. Lecturer tended to give this technique to check students' writing from their e-reflection. The PETA course itself was conducted during four months and through out the course each student should submit six e-reflections.

Students got the feedback of their grammatical errors in writing. Then, it helps them to improve their grammatical competence by reducing the grammatical errors. A number of researchers have reported that feedback examined the effectiveness of directive feedback in improving students' writing skill. Data was collected from record observation which is gained from PETA e-reflection journal and students' interview. The main research question was about on how directive feedbacks can improve students' writing skill in grammatical competence. This research also tried to explore these four questions below:

1) What are the commonest grammatical errors made by students?

2) What are the commonest grammatical errors students no longer make in the end of the course?

3) Why students still make the commonest grammatical errors in the end of the course?

4) How students' feeling about directive feedback can improve their writing skill?

This research ignores some extraneous variables such as gender, age and cultural background of the participants.

\section{Literature Review}

\subsection{Directive feedback}

One of the most significant and most contentious themes in the feedback literature is the issue of error correction. Therefore, directive feedback is used strategy to check students' grammatical error in writing. Directive feedback identifies student's errors and highlights the corrective action to be taken to achieve the appropriate response (Sanders, 2005). 


\subsection{Directive feedback improves students' writing skill}

In order to help students achieve writing ability successfully, feedback is one of the most important tasks to encourage the development of students' writing (Hyland, 2003).

According to Ellis (2009), teachers choose directive feedback as strategies to improve students' writing. Directive feedback tells the student what needs to be fixed or revised. Such feedback tends to be more specific than facilitative feedback, which provides comments and suggestions to help guide students in their own revision and conceptualization. This type of feedback can provide information that may be useful for correcting inappropriate task strategies, procedural errors, or misconceptions (Narciss \& Huth, 2004). The corrective function effects appear to be especially powerful for feedback that is more specific (Baron, 1988; Goldstein, Emanuel, \& Howell, 1968), which is described next. Directive feedback may help students to change the particular errors to the correct one since teachers provide them with correct forms. Besides that, this feedback can be a powerful motivator when delivered in good response so that students are encouraged not to repeat their errors again.

\subsection{Directive feedback encourage students}

Motivation has been shown to be an important mediating factor in learners' performance (Covington \& Omelich, 1984), and feedback can be a powerful motivator when delivered in response to goal-driven efforts. Some researchers suggest that the learner's goal orientation should be considered when designing instruction, particularly when feedback can encourage or discourage a learner's effort (Dempsey et al., 1993). In fact, some research has shown that directive feedback may actually be more helpful than facilitative-particularly for learners who are just learning a topic or content area (e.g., Knoblauch \& Brannon, 1981; Moreno, 2004).

\subsection{Students' perspective toward directive feedback}

Studies have been shown that even when students do understand the feedback, they may not know how to use it in a revision (Conrad \& Goldstein, 1999; Goldstein \& Khols, 2002). However, despite this, studies have revealed that students regard teacher feedback very highly (Enginarlar, 1993; Hyland. F, 1998; Leki, 1991).

Studies have also shown that while students $d o$ want feedback on content and ideas, they particularly favor feedback on grammar. Indeed, research on student preferences has consistently found that they expect teachers to comment on their errors and are frustrated if teachers do not (Cohen \& Cavalcanti, 1990; Hedgcock \& Lefkowitz, 1994; Hyland. F, 1998; Ferris \& Roberts, 2001). This may explain why teachers provide so much feedback on grammar, even when there is a de-emphasis of error correction within the educational institution (Leki, 1991; Montgomery \& Baker 2007).

It is clear that most students want their grammatical errors to be corrected. Unfortunately, research on students preferred methods of receiving corrective feedback has not come to any firm conclusions. Some studies have shown that students prefer direct error correction (E.g. Lee, 2005, 2008), while others suggest a preference for more indirect methods. Studies by Saito (1994) and F. Hyland (2001), for example, found that students were positive about receiving clues rather than corrections as they recognized that it encouraged them to be more active in their use of feedback.

\section{Significance of the Study}

As mentioned above, there is a need to address the issue of using directive feedback to improve students' writing skill and also to investigate students' feeling toward this feedback. The present study has benefits for both students and teachers. For the students, it has the potential of developing students' ability in writing with good grammar. Teachers also get better insights about directive feedback which is as consideration to use this technique in giving feedback of students' writing. Therefore, the researcher believed that this study can report the result of directive feedback for improving students' writing skill in grammatically. Moreover, the recommendations could contribute to enhancing the effectiveness of directive feedback in improving students' writing skill and the level of students' writing skill improvement.

\section{Methodology}

This research was conducted in the form of a case study since the researcher selected for closer examination a typical example from a small number of other examples. Case study research "seeks to understand specific issues and problems of practice" (Merriam, 1988, p. 23) through a detailed examination of a specific group of people, a particular organization, or a selected activity. This research was conducted in three weeks. In addition this research is a historical research which means this research examine about past event that has already happened.

\subsection{Participant}

Three participants participated in this case study were from English students' cohort 2010 from section D who took PETA (Principle of Effective Teaching and Assessment) Course. The participants were selected based on Purposive selection. Reasons behind the selection were because only section D cohort 2010 whose lecturer gave directive feedback and time constraint.

\subsection{Data Collection}

The data collection was gained from record observation and students' interview.

Record observation was obtained from students' e-reflection during PETA course. There are six e-reflections for each of students. Furthermore, the researcher interviewed each of participants by using an unstructured interview (Cohen \& Manion, 1986, pp. 291-314). The researcher use recording to record during interview. After that, the result of the record 
is transcript into written notes. The interview provided information on students' opinion toward their teacher's strategy in using directive feedback and their feeling regarding that type of feedback. A qualitative interview outline was prepared beforehand to support the interview and reduce interview subjectivity.

\section{Findings}

After collecting the data, the researcher classified the data into six charts to find out the commonest grammatical errors made by the students. The researcher only listed the five commonest grammatical mistakes from each e-reflection. Below are the charts from the first until the sixth e-reflection:

\section{First e-reflection}

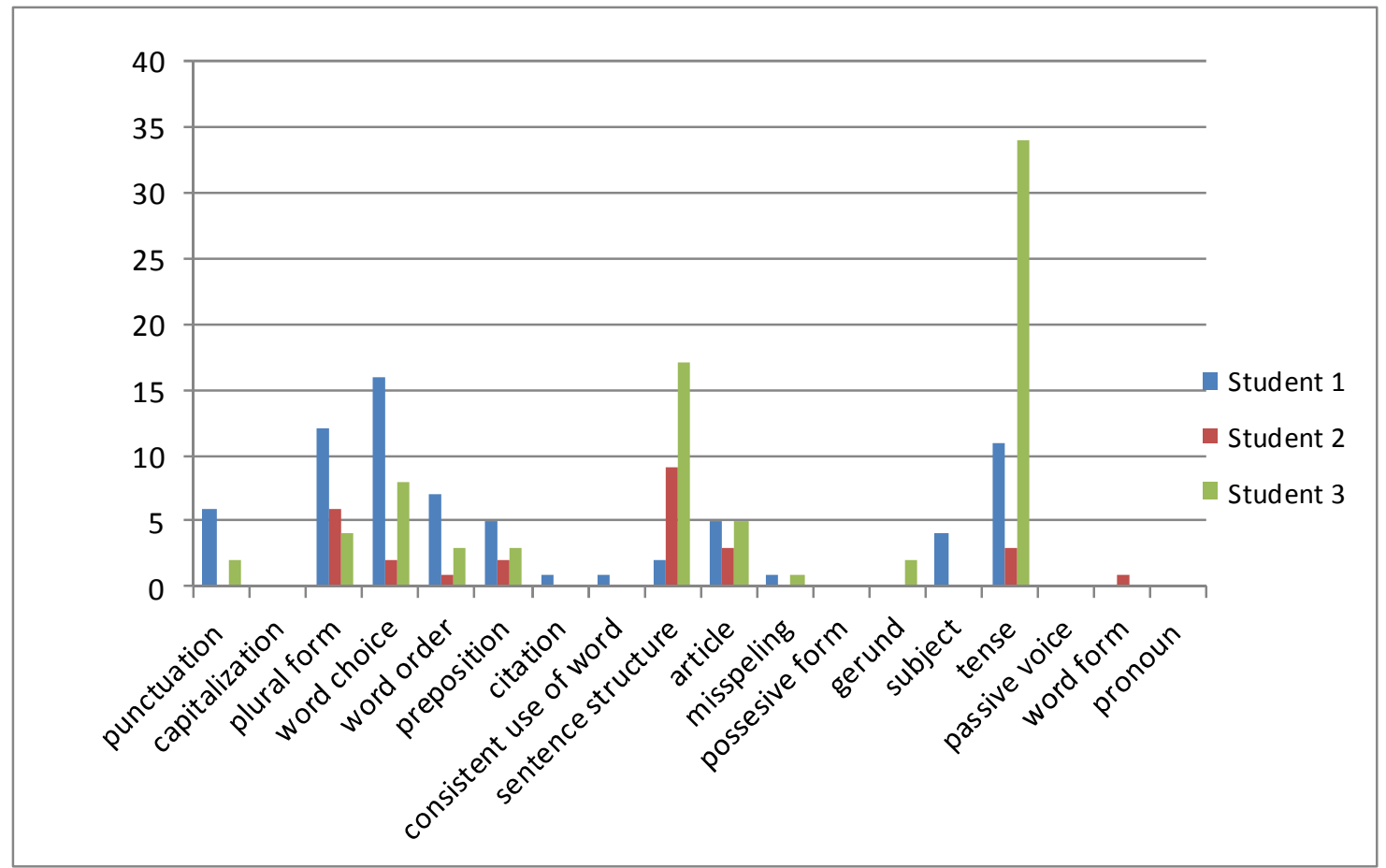

Based on the chart above, the result shows that the commonest grammatical errors made by all participants are tenses, sentence structure, word choice, plural form and article.

\section{Second e-reflection}

\section{E-reflection 2}

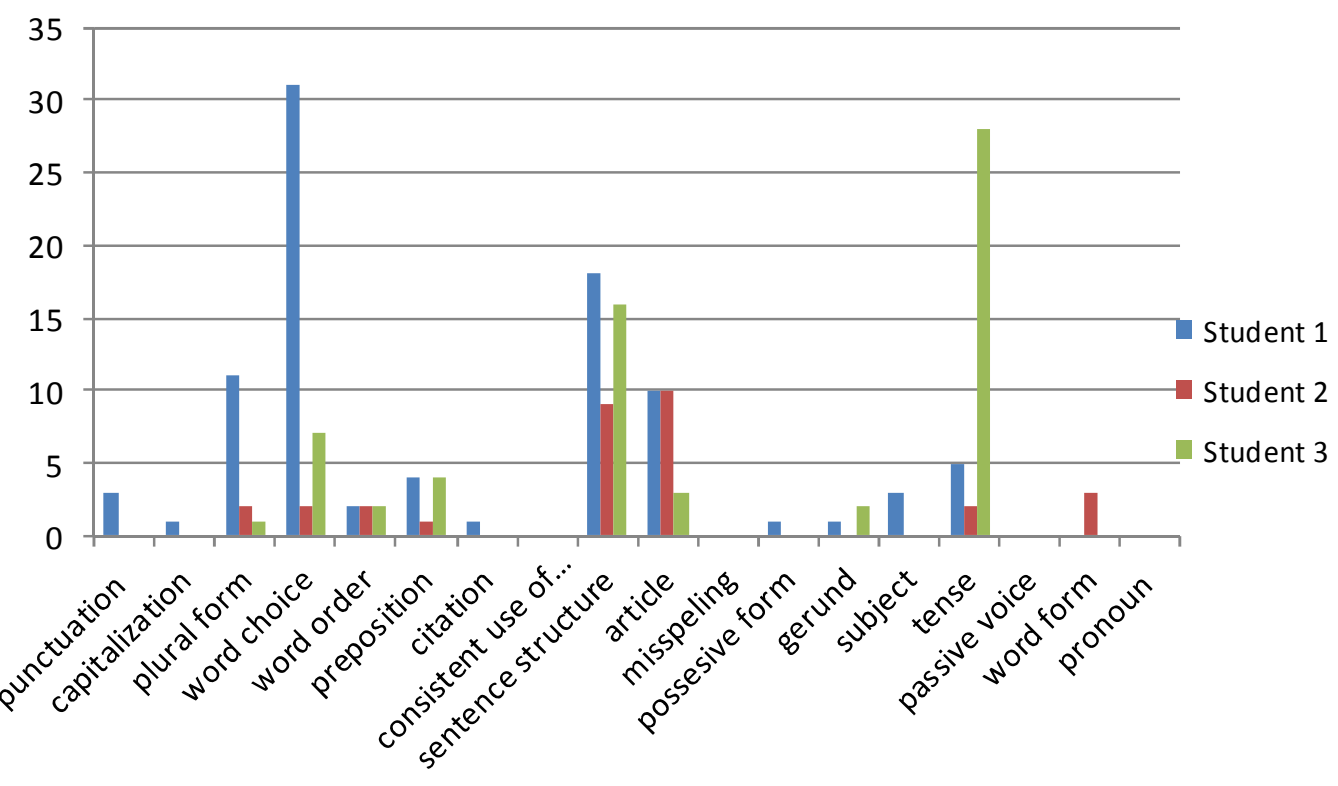


The chart above demonstrates that the commonest grammatical errors found in participants' e-reflection are word choice, tenses, sentence structure, article and plural form.

\section{Third e-reflection}

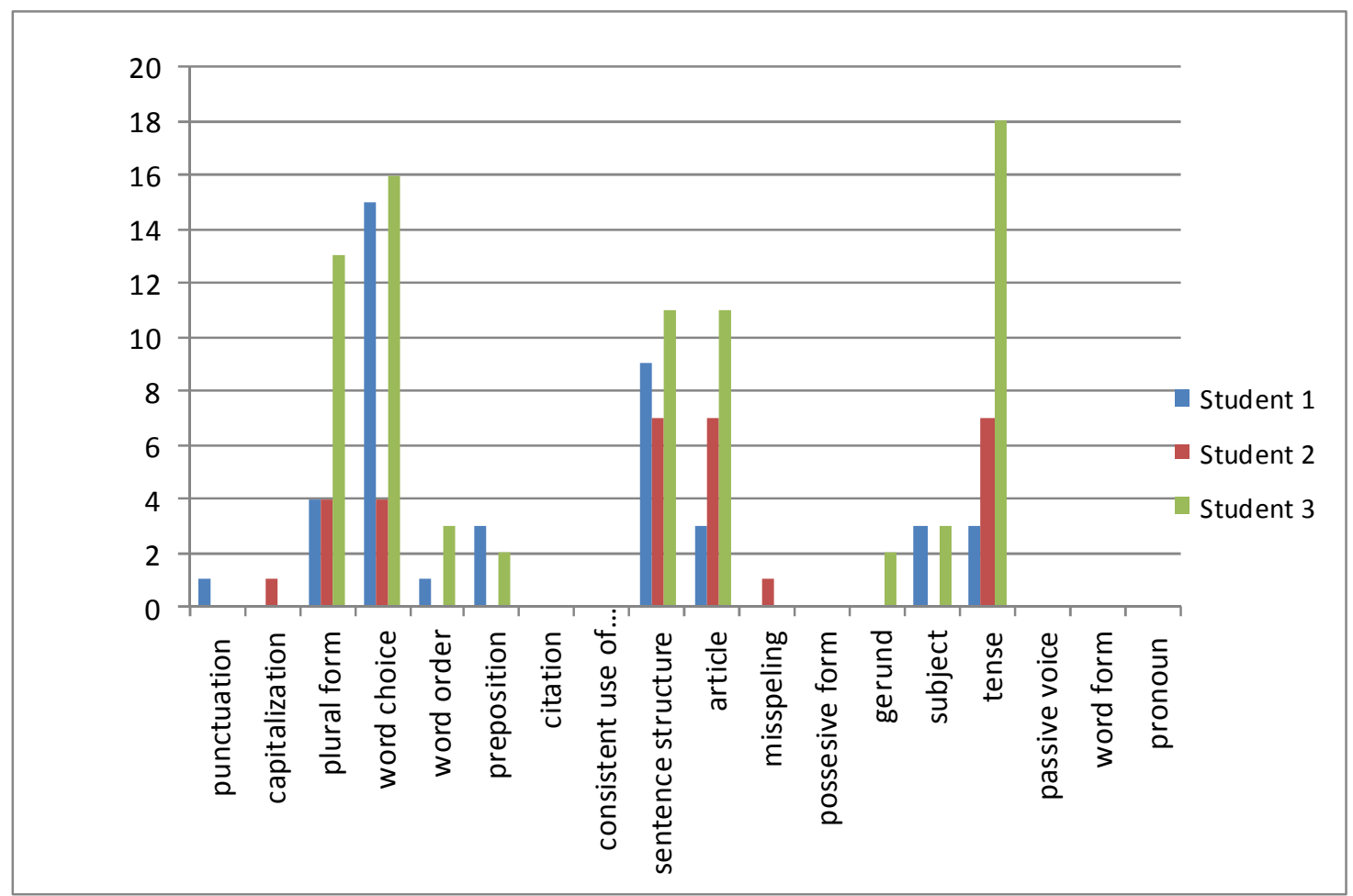

The chart above indicates that the commonest grammatical errors made by participants are word choice, sentence structure, tense, article, and preposition.

\section{Fourth e-reflection}

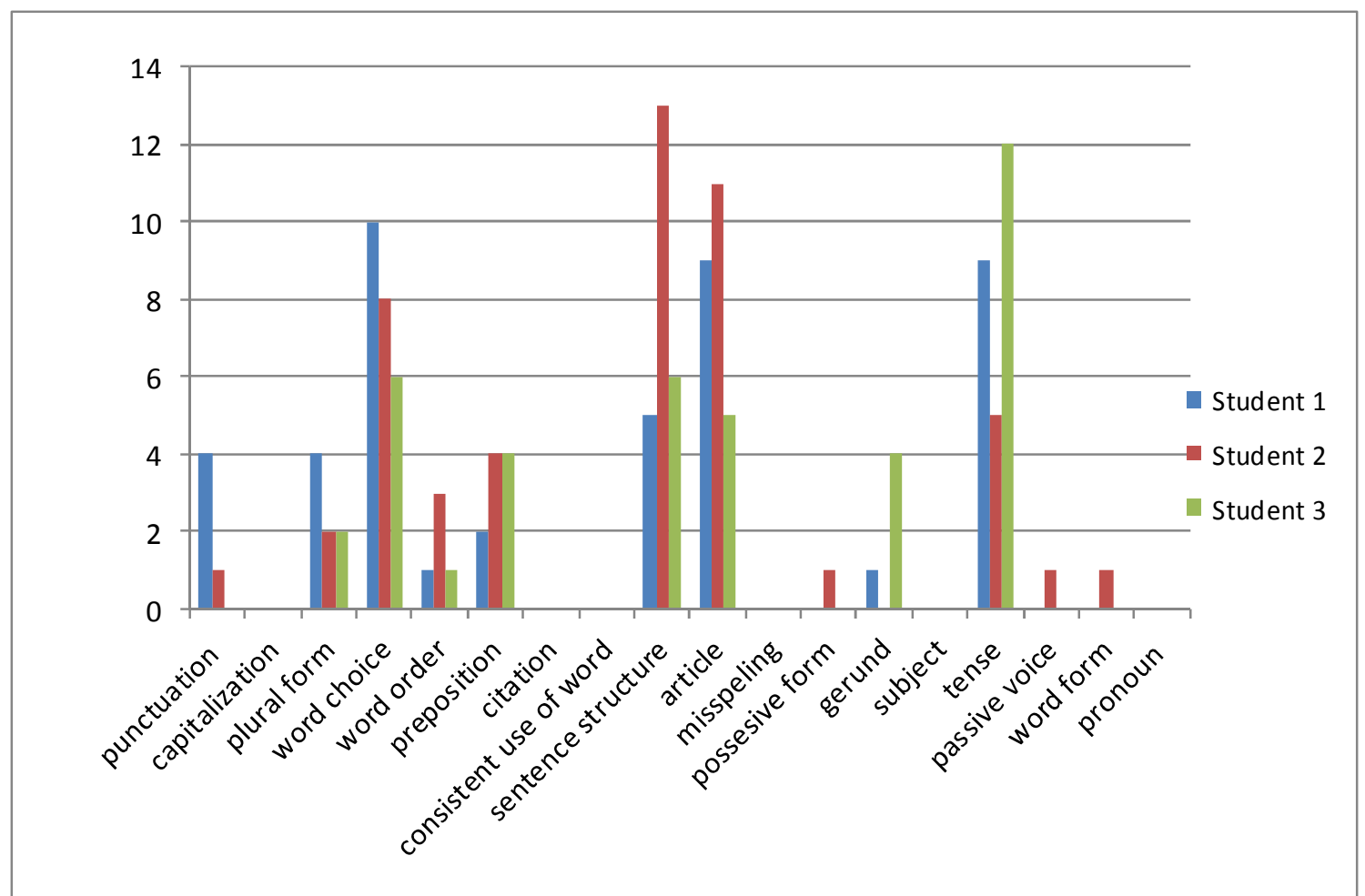

According to the chart, the commonest grammatical errors found in the participants' e-reflection are tense, sentence structure, article, preposition, and word choice. 


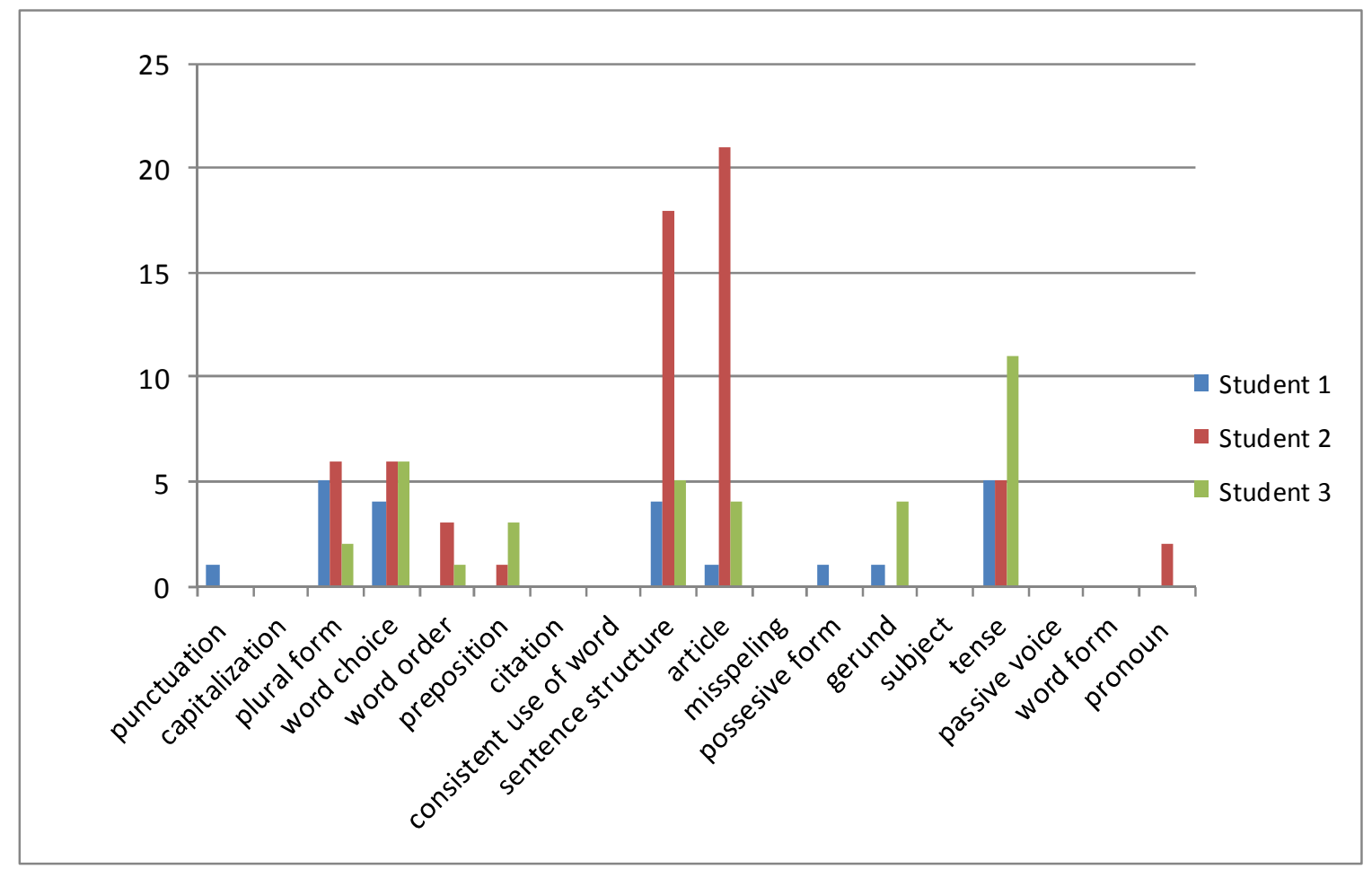

The chart above illustrates that the commonest grammatical errors made by the students are article, sentence structure, tenses, word choice, and plural form.

\section{Sixth E-reflection}

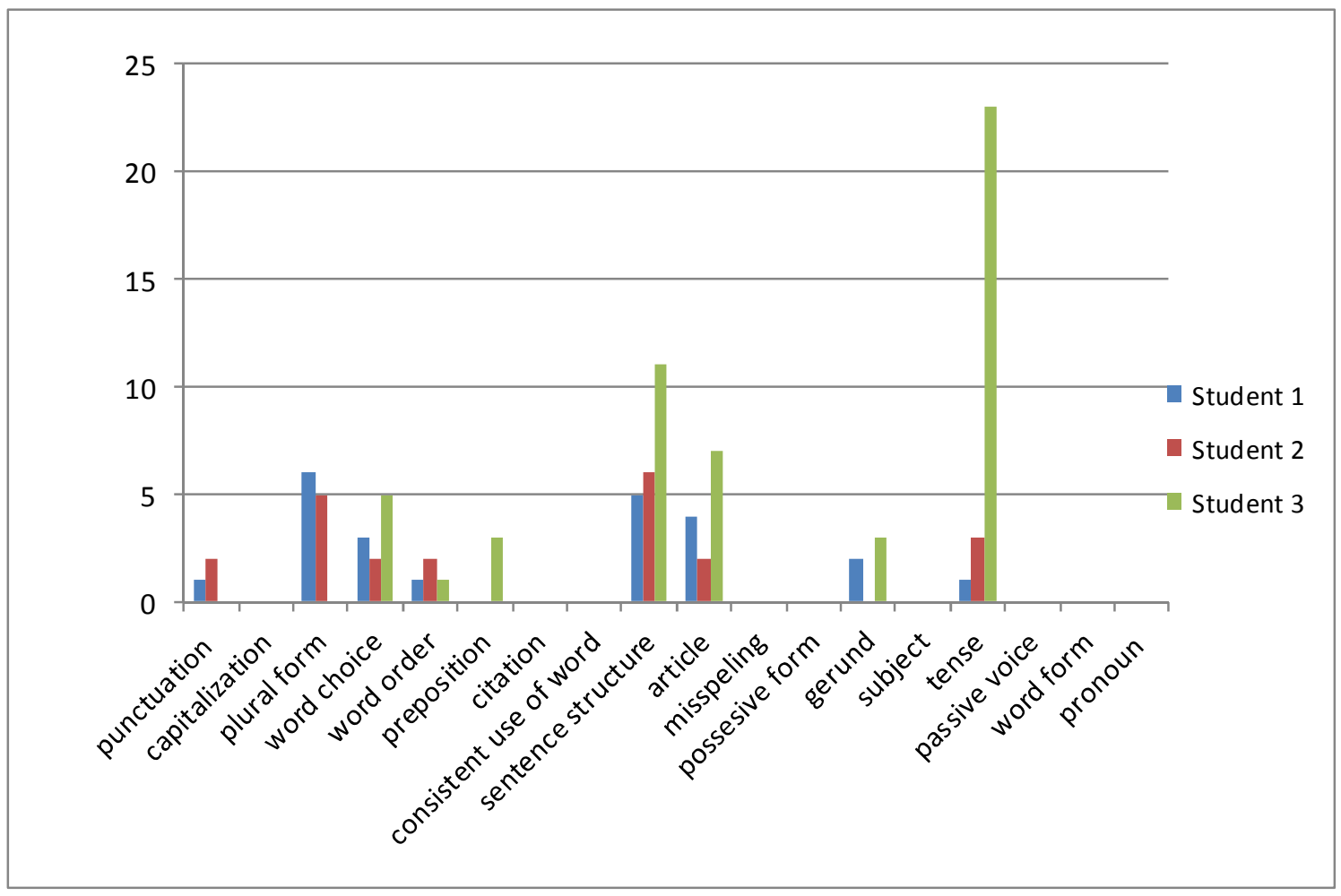

The chart indicates that the commonest grammatical errors found in participants' e-reflection are article, sentence structure, tenses, word choice, and plural form.

So, after the researcher classified the data and presented it into chart, it was concluded that the commonest grammatical errors made by the participants are tense, sentence structure, article, word choice, plural form and preposition. To be able to analyze the development of each student' commonest grammatical errors from the first until the sixth ereflection, the researcher classified each grammatical errors items into line graphs. Below are the line graphs of each grammatical errors item: 


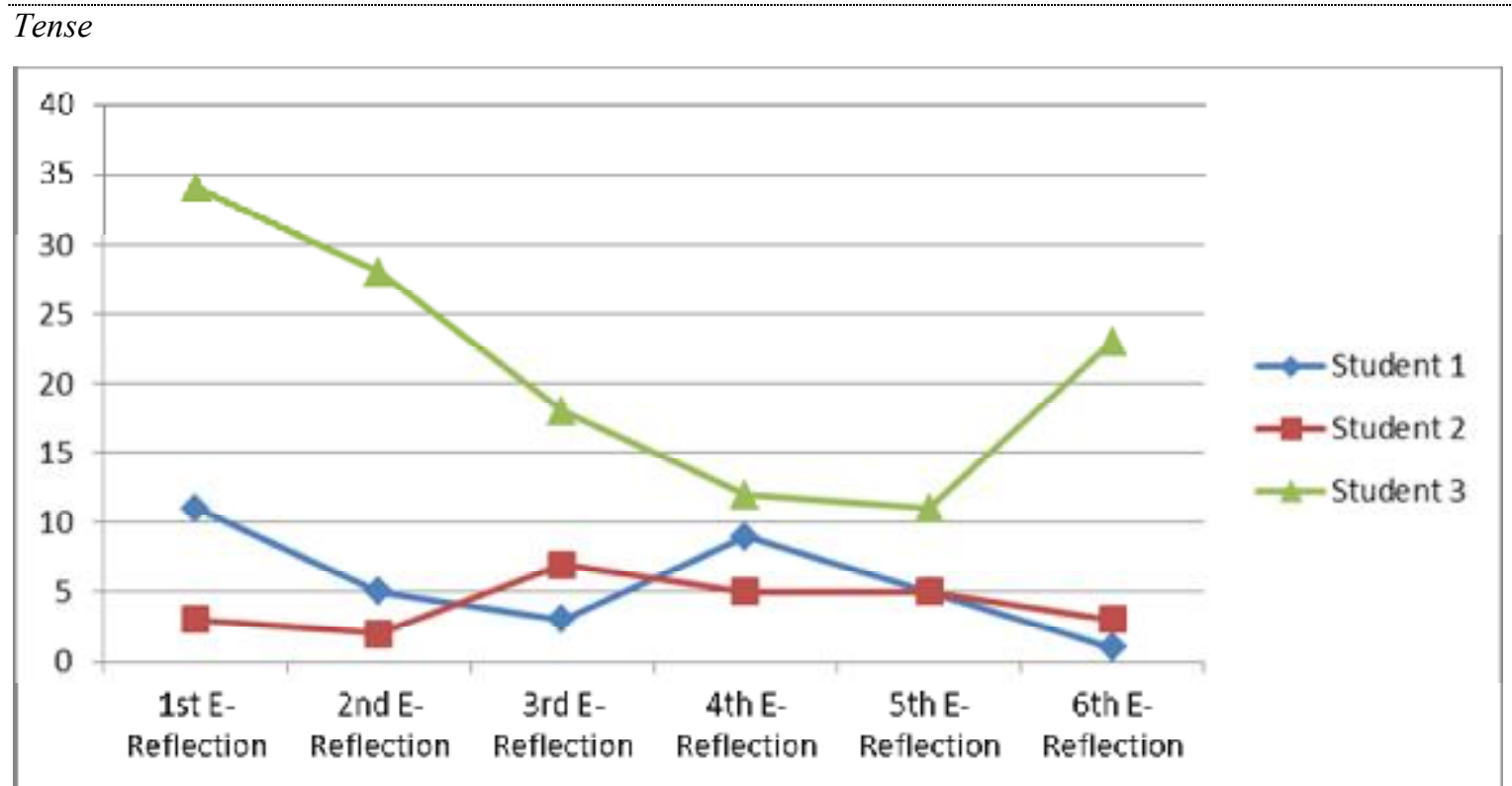

As indicated by the line graph above, it can be seen that the number of mistakes made by student 1 from the first ereflection to the last e-reflection is decreasing, from 11 mistakes to 1 mistake. Moreover, student1's line shows a quite constant descending rate from one e-reflection to others, except in the fourth e-reflection when a sudden increment number of mistakes occur.

In other hand, student 2' line graph illustrates the number of mistakes made by the student 2 does not change from the first e-reflection to the sixth e-reflection (the mistakes are 3 mistakes). Furthermore, student 2' line graph has a quite constant flow, which means student 2 only made mistakes in range 3 until 6 mistakes.

Last, student 3's line graph shows that student 3' mistake in using tense is decreasing, from 34 mistakes to 23 mistakes. In addition, student 3' shows a constant mistakes descending from one e-reflection to others, with exception in the last e-reflection where the mistakes suddenly increase again.

Sentence structure

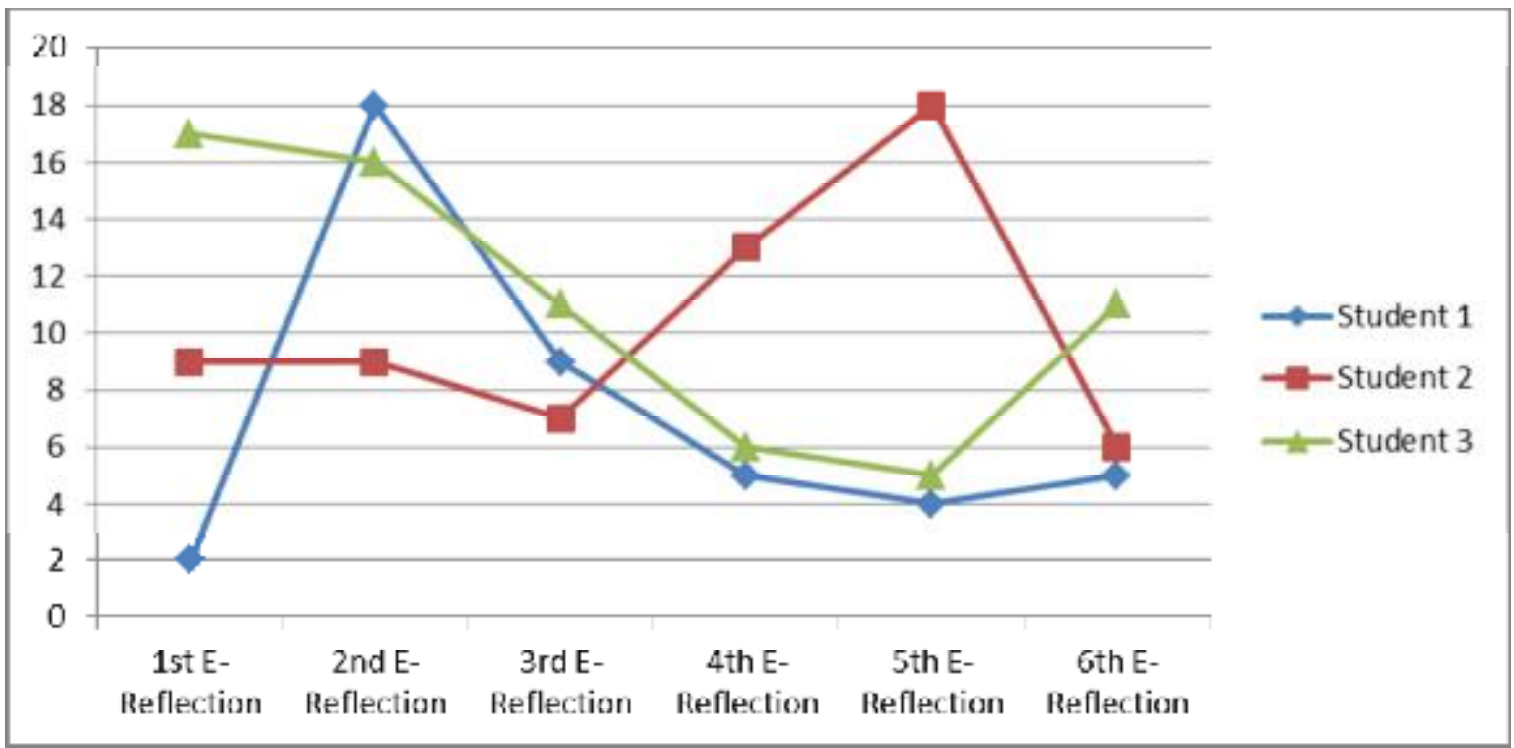

Based on the line graph above, it can be seen that the number of mistakes made by student 1 is increasing, from 2 mistakes to 4 mistakes. It also shows that there is an extreme increment of made mistakes in the second e-reflection. Yet, the number of mistakes slowly decreasing until it only remains 4 mistakes in the last e-reflection.

Meanwhile, student 2' line graph demonstrates that the number of mistakes made by student 2 is descending from 9 mistakes to 6 mistakes. Aside from that, the flow of the line graph is quite dynamic with constant increasing number of mistakes in the fourth and fifth e-reflection. 
Last, student 3's line graph shows that student 3' mistake in using sentence structure is reducing from 17 mistakes to 11 mistakes. Moreover, the line graph's flow shows a constant descending of made mistakes from first e-reflection to fifth e-reflection, with exception in the sixth e-reflection. There are an increment number of made mistakes.

Article

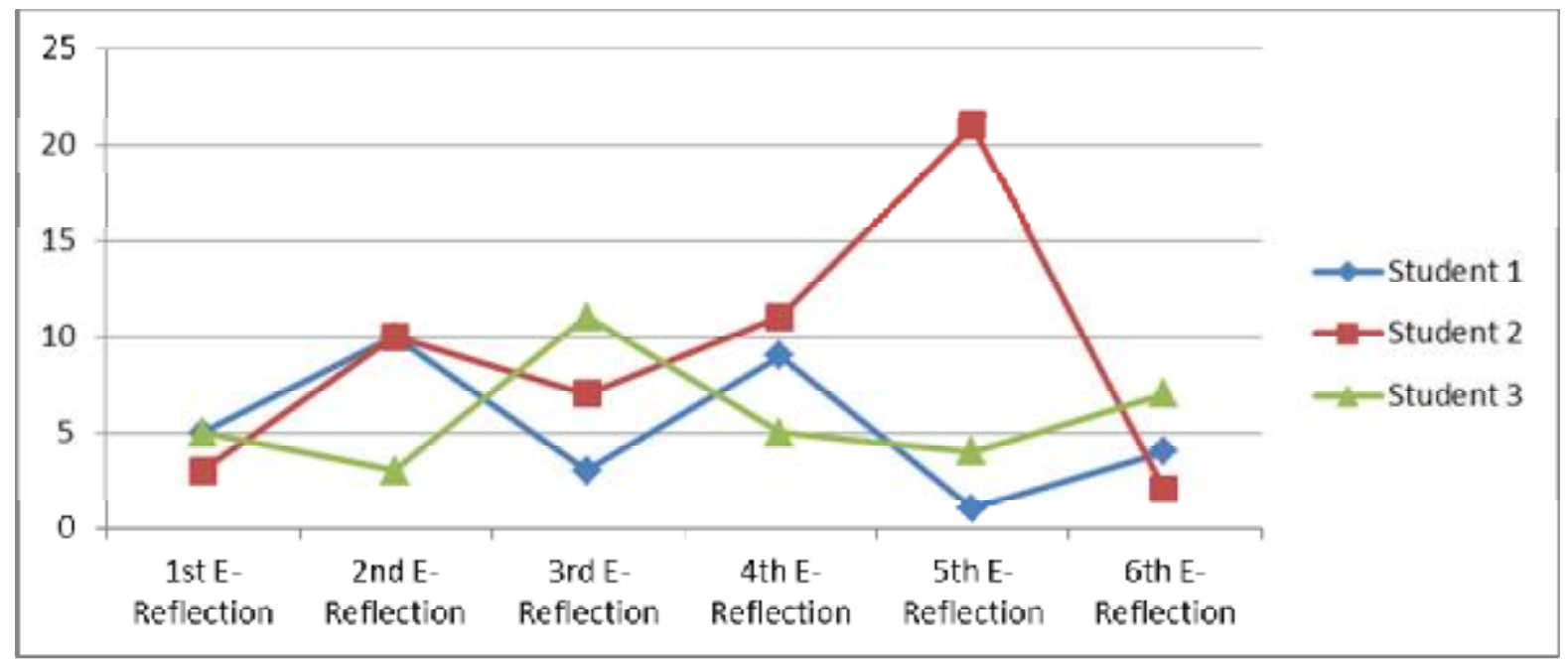

According to the line graph above it can be seen that student 1's line graph is descending from the first e-reflection (5 mistakes) to the last e-reflection (4 mistakes). However student1's line graph does not show a constant descending from one e-reflection to others. It has dynamic flow. For instance student 1' mistakes increase until 5 mistakes (the total mistake are 10 mistakes) in the second e-reflection and decrease in the third e-reflection, just to ascending again in the fourth e-reflection.

Meanwhile, student 2' line graph represents that the number of mistakes made by the student 2 does not change from the first e-reflection to the sixth e-reflection (the mistakes are 3 mistakes). Beside, the line flows of student 2 also very dynamic.

Last, student 3's line graph shows that student 3' mistake in using article do not reducing. In contrary the total mistakes increase from 5 mistakes to 6 mistakes. Furthermore, student 3' line graph does not show a constant mistakes ascending from one e-reflection to others. The flow dynamically changes.

\section{Word choice}

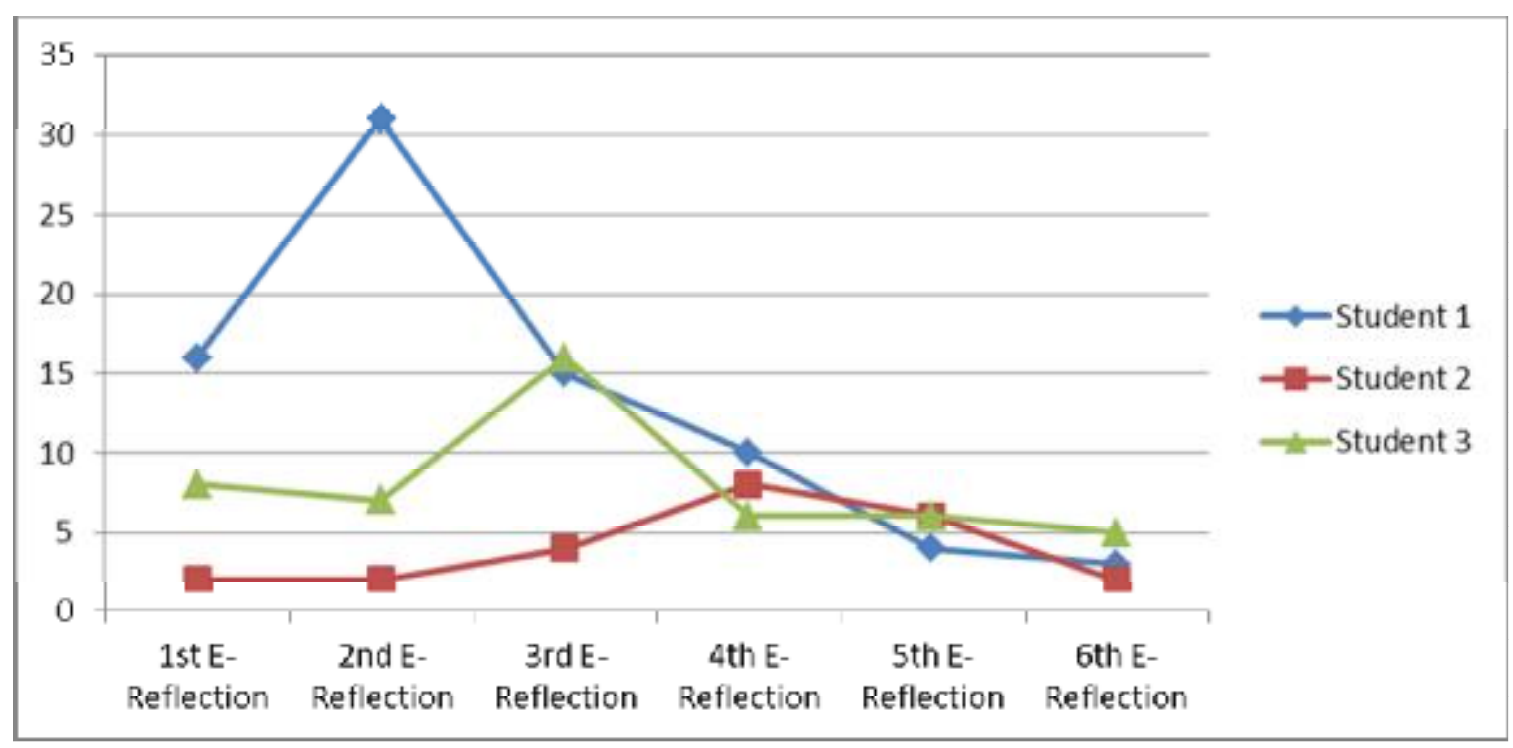

The graphic illustrates the three students' mistakes in all of e-reflections. The student 1's line graph is descending from the first e-reflection (16 mistakes) to the sixth e-reflection ( 3 mistakes). The good progress of descending mistakes is shown by the student 1 's line graph. However, the great ascending also shows in the second e-reflection (31 mistakes).

The student 2's line graph is static line; there is no improvement ( 2 mistakes only). Yet the process from the first until the end of e-reflection is up and down, but it is not an extreme descending and ascending.

The student 3's line graph shows significant descending. Although, the third e-reflection is ascend until 16 mistakes. 


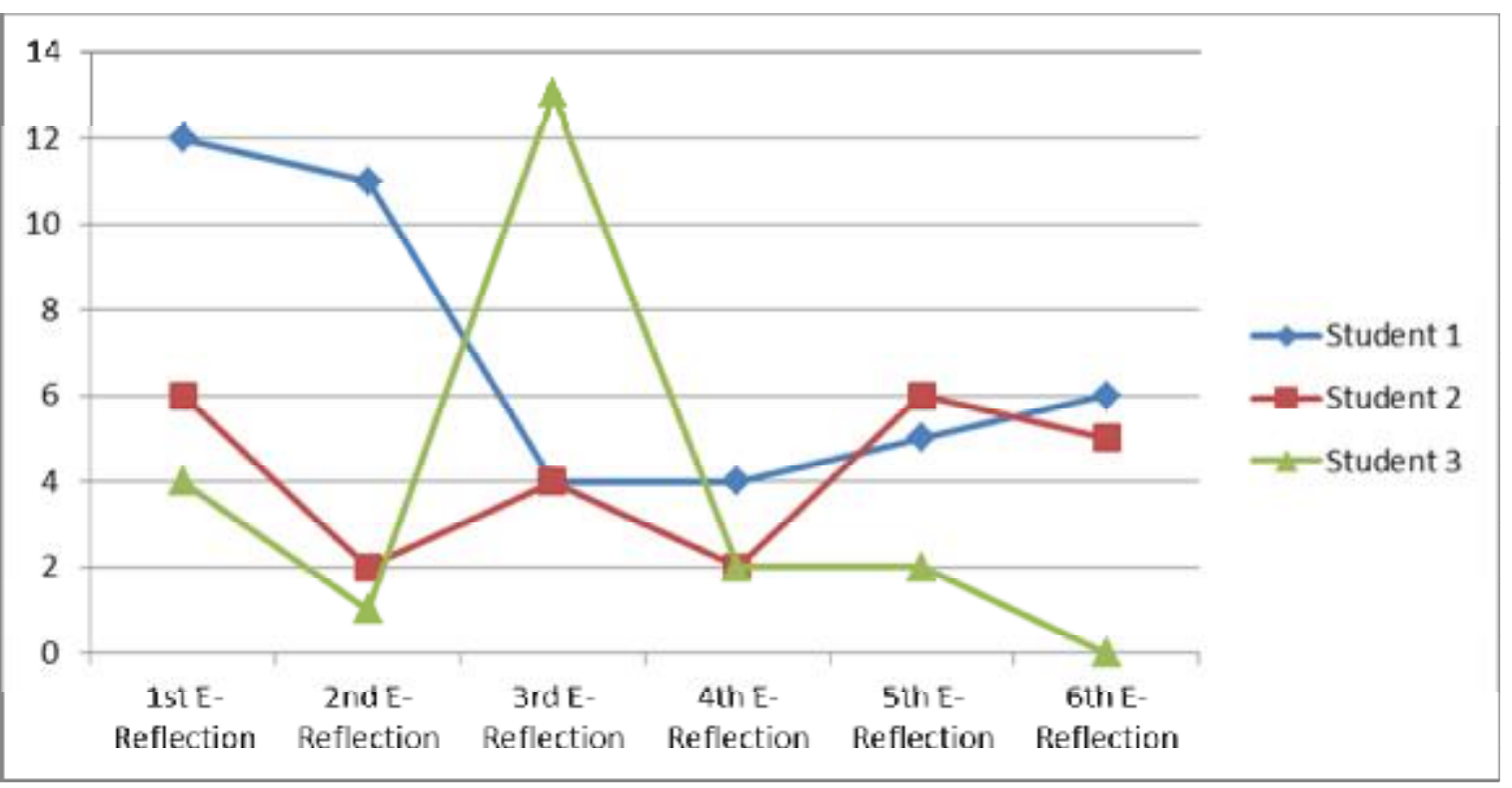

The graphic above indicates that the student 1's line graph shows the significant improvement from the first e-reflection (12 mistakes) to the last e-reflection (6 mistakes), although, it is not descend constantly but the mistakes is around 4 until 6 .

The student 2's line graph shows a bit constant graphic because the descending does not go far from the first (6 mistakes) until the last reflection (5 mistakes).

The student 3's line graph is descending from the four mistakes in the first e-reflection to the perfect one (no mistake) in the last e-reflection. In spite of this improvement, the student 3's line shows the extreme line in the third e-reflection (13 mistakes). The other lines show the descending line constantly.

\section{Preposition}

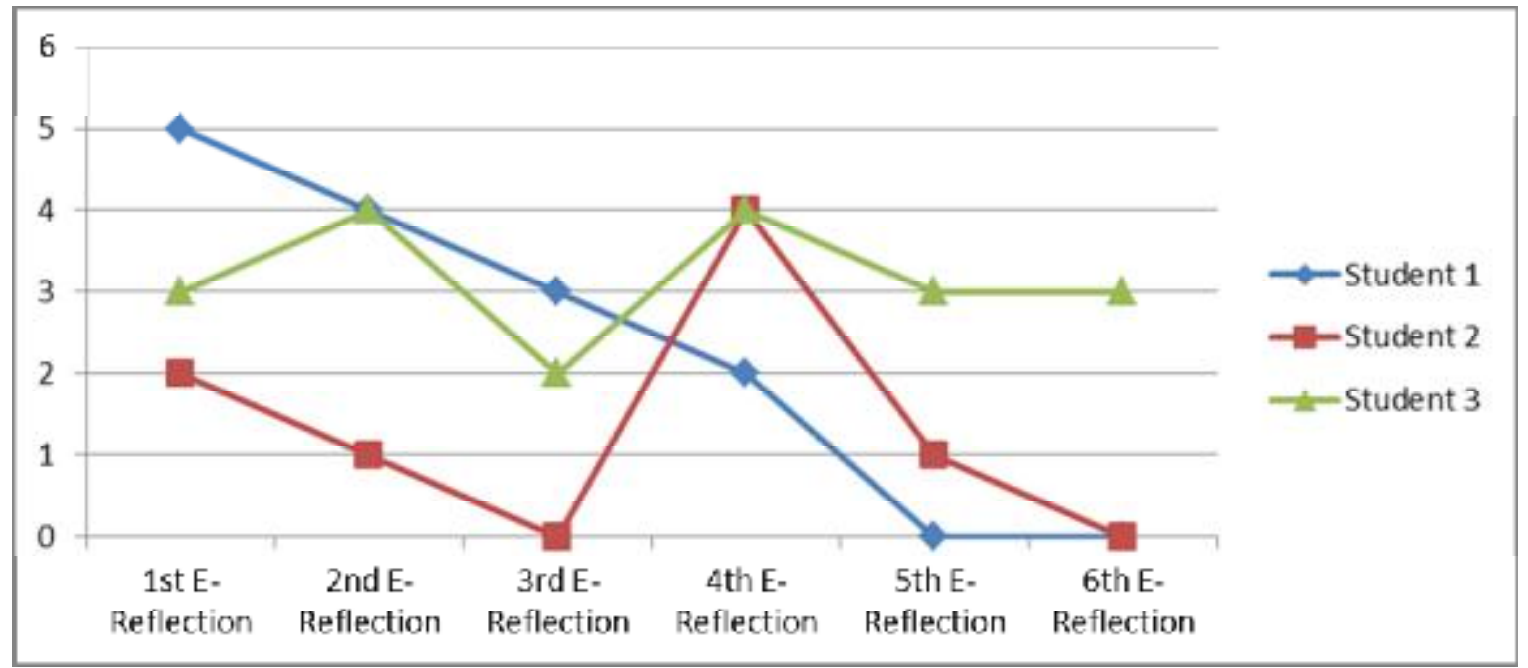

According to the line graph above, student 1's line graph is descending from the first reflection (5 mistakes) to the last reflection (no mistake). It shows constant descending. Student 2's line graph is descending also from first e-reflection (2 mistakes) to the last e-reflection (no mistake). Yet in the fourth e-reflection, student 2's line graph is ascending from there is no mistake (third e-reflection) to 4 mistakes (fourth e-reflection). It is followed by the descending line until the last e-reflection.

The next is student 3's line graph; it shows that the line is static means that the mistakes do not improve. There are three mistakes at the first e-reflection and three mistakes also in the last e-reflection. However, the line is dynamic from the first reflection ( 3 mistakes), the second reflection (4 mistakes), the third reflection ( 2 mistakes), the fourth reflection (4 mistakes), the fifth and the sixth reflection have the same mistakes (3 mistakes).

\section{Discussion}

In this study the researcher investigated about one main question which is questioning the relation between directive feedbacks and students' writing skill. Aside from that, the study examined other four questions. Those are the 
commonest grammatical errors made by students, the number of commonest grammatical errors that are no longer made by students, the reason on why students still make the commonest grammatical errors and students' opinion about the possibility of directive feedback improves their writing skill.

According to the collected data, it was found that there are six commonest grammatical errors made by all the participants. Those are word choice, tense, sentence structure, preposition, plural form and article. All of those errors are the typical grammatical errors make by ESL (English as Second Language) and EFL (English as Foreign Language) learners.

Aside from that, the researcher also discovered that the commonest grammatical errors made by students still exist until the end of the course (proven by referring to the sixth e-reflection). Then, figuring out that not all of the commonest grammatical errors number is reducing. Every participant has their own pattern of errors. For instance, in sentence structure's case, student 2 and 3 numbers of errors are descending. Yet, student 1number of errors is ascending.

The graph lines are so dynamic and unpredictable. So, based on the collected data we assume that all participants still made some of commonest grammatical errors until the end of the course and there are no commonest grammatical errors that vanish. This situation might happen because of two important factors. Those are the length of the e-reflection and students' awareness to the directive feedback.

First is the length of the e-reflection, as indicated by the collected data, the longer the e-reflection the more grammatical errors possible to occur. For example, in the student's 2 fifth e-reflection, there is an extreme increment number of article errors because of the length of the e-reflection (longer than the previous e-reflection). The similar case also happen to student 1 , the word choice errors is greatly increase in the second e-reflection because of the length of the ereflection itself.

Second is the students' awareness to the directive feedback. The more time students spend to read and learn from the given feedback, the fewer errors students will make. Unfortunately the participants of this study do not read carefully and only skimming the given feedback (based on the interview result, it can be seen in the appendix), so it explains the dynamic and inconsistent graph line' flow of the participants.

\subsection{Students' reaction}

Each of participants were interviewed by using unstructured interview and provided some insight into students' reaction to the directive feedback given by the lecturer. A qualitative interview outline was prepared beforehand to support the interview and reduce interview subjectivity. The outline consisted of the following four questions:

1. How do you feel about directive feedback given by the lecturer?

2. Do you read carefully the directive feedback given by the lecturer?

3. What have you learned from the given feedback?

4. How do you think directive feedback help you to improve writing skill?

From the first question, two of students feel that directive feedback is good way and help them in checking grammatical error. Besides that, it shows that the lecture cares of the students. However, the rest student thinks that facilitative feedback should be used for PETA course instead of directive feedback. Directive feedback sometimes changes the student' intended meaning.

According to me, feedback which is given from the lecturer is not as what we expected before. The feedback for PETA course should focus with content. However, the lecturer just focuses with the grammatical error. Then, it is should be stated in the first place. (Student 1)

Honestly, directive feedback really helps me. The lecturer does not limit us about the content but more focus with the grammar and structure. So, I am happy (Student 2)

Good, from that feedback I just realized that lecturer cares with us. However, the weakness is lack of monitor from lecturer to remind students whether they will repeat the same mistake from the previous reflection. (Student 3)

For the second question about whether students read carefully the directive feedback given by the lecturer. The result shows that all students read the given feedback. One of them just skimmed the feedback given and not really detail in reading it.

I read it in order I know the error one. Because of short reflection so it makes me easier to identify the feedback from lecturer. (Student 1)

I do not read detail but just skimming and focusing with the mistakes. (Student 2)

I read all the feedback and it makes me realize some error parts that should be improved. I learn from that feedback however sometimes many feedbacks also discouraged me to read it. (Student 3)

The third question asked about what students have learned from directive feedback. Two of students notice some grammatical mistakes they made from reading the given feedback. They think that learning grammatical errors not only from given feedback but also from others. However, given feedback also helps them in learning those errors. The male student learns $50 \%$ of the feedback. 
First is structure. Sometimes, I am confused to put the right verb, use the right tenses and how to make effective sentences. (Student 1)

That's what makes me dilemma. Actually for grammar I learn from many sources not only from this feedback but it still helps me for sure. (Student 2)

I learn and 50 percent I apply it. (Student 3 )

The last question shows that directive feedback is useful for improving grammatical competence. They recommend PETA course to define the objective of assessment from the first time. Directive feedback gives portion in helping them for improving writing skill.

Actually, if the assessment of reflection also focuses in grammar, we will consider it. the criteria of feedback should be stated clearly whether focus on grammar or more in content. (Student 1)

Yes, it could. I think my writing skill can improve not only from her feedback but also from other learning. (Student 2)

It helps me in improving my writing. Yet, I also learn how to improve it by practicing and learning form others. (Student 3)

\section{Conclusion}

In summary, the researcher concluded that directive feedbacks can improve students' writing skill with one condition. That is students should be aware of the feedbacks given by the lecturer and learn it. This conclusion opened possibility for further research to find the level of effectiveness of directive feedback in improving students' writing skill and the level of students' writing skill improvement.

Last, this study has limitation in the participant number so the result cannot explain the whole phenomena that happen in real world context. Aside from that due to the limited time of conducting the research, the researcher cannot explore the case more deeply and discuss the finding in greater details.

\section{References}

Boramy, S. (2010). Using directive and facilitative feedback to improve student writing: A case study of a higher education setting in Cambodia. Cambodia: Language Education in Asia

Calvo, A. R., \& Ellis, A. R.(2010). Students' conceptions of tutor and automated feedback in professional writing. The University of Sydney. Retrieved fromhttp://www.jee.org/2010/october/11.pdf, January 26, 2013

Ellis, R. (2009). A typology of written corrective feedback types'. ELT Journal, 63: 97-107.

Herrero, A.H. (2007). Journals: A Tool to Improve Student's writing Skills. Retrieved from http://revista.inie.ucr.ac.cr/uploads/tx_magazine/journals.pdf, January 18, 2013

Owens, Janeane. Feedback in second language writing: Teacher and student attitudes and preference. Retrieved from http://www.academia.edu/1885384/FEEDBACK_IN_SECOND_LANGUAGE_WRITING_TEACHER_AND_STUDE NT_ATTITUDES_AND_PREFERENCES, January 20, 2013

Shute, J.V. (2007). Focus on formative feedback.. ETS, Princeton, NJ. Retrieved from http://www.ets.org/Media/Research/pdf/RR-07-11.pdf, $\quad$ January $\quad 18,2013$. 


\begin{tabular}{|c|c|c|}
\hline \multicolumn{3}{|l|}{ Appendix } \\
\hline $\begin{array}{c}\text { Categories of the } \\
\text { Grammatical } \\
\text { Mistake }\end{array}$ & The Mistakes Made & Revision \\
\hline Capitalization & $\begin{array}{l}\text {... we are supposed to make our students learn } \\
\text { throughout the levels as recommended by bloom's } \\
\text { taxonomy... }\end{array}$ & $\begin{array}{l}\text {... we are supposed to make our students learn throughout } \\
\text { the levels as recommended by Bloom's taxonomy... }\end{array}$ \\
\hline Plural form & In the $21^{\text {st }}$ century, teacher has many things to do... & In the $21^{\text {st }}$ century, teachers have many things to do... \\
\hline Word choice & . Teachers now have big duty to be effective teachers... & $\begin{array}{l}\text { Teachers now have big responsibilities to be effective } \\
\text { teachers... }\end{array}$ \\
\hline Word order & For this session, I have learned about micro teaching... & I have learned about micro teaching from this session... \\
\hline Preposition & ... today I have learnt that many teachers at the past ... & ... today I have learnt that many teachers in the past ... \\
\hline Citation & $\begin{array}{l}\text { According to Chris Kyriacou (2007, Effective } \\
\text { Teaching in Schools) there are three interrelated } \\
\text { perspectives of an effective teaching... }\end{array}$ & $\begin{array}{l}\text { According to Chris Kyriacou (2007) there are three } \\
\text { interrelated perspectives of an effective teaching... }\end{array}$ \\
\hline Consistent use of word & $\begin{array}{l}\ldots \text { which are from the points of view of teachers, pupil } \\
\text { and activities ... }\end{array}$ & $\begin{array}{l}\ldots \text { which are from the points of view of teachers, students } \\
\text { and activities ... }\end{array}$ \\
\hline Sentence structure & $\begin{array}{l}\text { At the fourth meeting I was taught about models of } \\
\text { teaching that divided into four items ... }\end{array}$ & $\begin{array}{l}\text { At the fourth meeting I was taught about four models of } \\
\text { teaching ... }\end{array}$ \\
\hline Article & Therefore we need the guidance called "lesson plan", ... & Therefore we need_a guidance called "lesson plan", ... \\
\hline Misspelling & $\ldots$ (and I though so). & ...(and I thought so). \\
\hline Possessive form & $\begin{array}{l}\text {... students got bored and did not get the points of the } \\
\text { teachers explanation. }\end{array}$ & $\begin{array}{l}\text {... students got bored and did not get the points of the } \\
\text { teachers' explanation. }\end{array}$ \\
\hline Gerund & $\begin{array}{l}\text { As we know that now teaching is taught by used a lot } \\
\text { of methods... }\end{array}$ & $\begin{array}{l}\text { As we know that now teaching is taught by using a lot of } \\
\text { methods... }\end{array}$ \\
\hline Subject & $\begin{array}{l}\ldots \text { we prepare to be effective teachers. It means that } \\
\text { teacher candidates ... }\end{array}$ & $\begin{array}{l}\ldots \text { we prepare ourselves to be effective teachers. It means } \\
\text { that teacher candidates ... }\end{array}$ \\
\hline
\end{tabular}




\begin{tabular}{|l|l|l|}
\hline Tense & At this session we are discussing about ... & At this session we discussed about ... \\
\hline Passive voice & It is more concern ... & $\underline{\text { It is more concerned ... }}$ \\
\hline Word form & We can not apply only one model of instructions. & We cannot apply only one model of instructions. \\
\hline Pronoun & $\begin{array}{l}\ldots \text { deliver materials to the students in order to make } \\
\text { students understand easily. }\end{array}$ & $\begin{array}{l}\ldots \text { deliver materials to the students in order to make them } \\
\text { understand easily. }\end{array}$ \\
\hline
\end{tabular}

\begin{tabular}{|c|c|c|c|c|c|c|}
\hline \multirow{2}{*}{$\begin{array}{c}\text { Categories of the } \\
\text { Grammatical Mistake }\end{array}$} & \multicolumn{6}{|c|}{ Student 1} \\
\hline & $1^{\text {st }}$ E-reflection & $2^{\text {nd }}$ E-reflection & $3^{\text {rd }}$ E-reflection & $4^{\text {th }}$ E-reflection & $5^{\text {th }} E-$ reflection & $6^{\text {th }}$ E-reflection \\
\hline Punctuation & $6(\operatorname{six})$ & 3 (three) & 1 (one) & 4 (four) & 1 (one) & 1 (one) \\
\hline Capitalization & - & 1 (one) & - & - & - & - \\
\hline Plural form & 12 (twelve) & 11 (eleven) & 4 (four) & 4 (four) & 5 (five) & 6 (six) \\
\hline Word choice & 16 (sixteen) & 31 (thirty one) & 15 (fifteen) & 10 (ten) & 4 (four) & 3 (three) \\
\hline Word order & 7 (seven) & 2 (two) & 1 (one) & 1 (one) & - & 1 (one) \\
\hline Preposition & 5 (five) & 4 (four) & 3 (three) & 2 (two) & - & - \\
\hline Citation & 1 (one) & 1 (one) & - & - & - & - \\
\hline Consistent use of word & 1 (one) & - & - & - & - & - \\
\hline Sentence structure & 2 (two) & 18 (eighteen) & 9 (nine) & 5 (five) & 4 (four) & 5 (five) \\
\hline Article & 5 (five) & 10 (ten) & 3 (three) & 9 (nine) & 1 (one) & 4 (four) \\
\hline Misspelling & 1 (one) & - & - & - & - & - \\
\hline Possessive form & - & 1 (one) & - & - & 1 (one) & - \\
\hline Gerund & - & 1 (one) & - & 1 (one) & 1 (one) & 2 (two) \\
\hline Subject & 4 (four) & 3 (three) & 3 (three) & - & - & - \\
\hline Tense & 11 (ten) & 5 (five) & 3 (three) & 9 (nine) & 5 (five) & 1 (one) \\
\hline Passive voice & - & - & - & - & - & - \\
\hline Word form & - & - & - & - & - & - \\
\hline Pronoun & - & - & - & - & - & - \\
\hline
\end{tabular}




\begin{tabular}{|c|c|c|c|c|c|c|}
\hline \multirow{2}{*}{$\begin{array}{c}\text { Categories of the } \\
\text { Grammatical Mistake }\end{array}$} & \multicolumn{6}{|c|}{ Student 2} \\
\hline & $1^{\text {st }}$ E-reflection & $2^{\text {nd }}$ E-reflection & $3^{\text {rd }}$ E-reflection & $4^{\text {th }}$ E-reflection & $5^{\text {th }}$ E- reflection & $6^{\text {th }}$ E-reflection \\
\hline Punctuation & - & - & - & 1 (one) & - & 2 (two) \\
\hline Capitalization & - & - & 1 (one) & - & - & - \\
\hline Plural form & $6(\operatorname{six})$ & 2 (two) & 4 (four) & 2 (two) & 6 (six) & 5 (five) \\
\hline Word choice & 2 (two) & 2 (two) & 4 (four) & 8 (eight) & 6 (six) & 2 (two) \\
\hline Word order & 1 (one) & 2 (two) & - & 3 (three) & 3 (three) & 2 (two) \\
\hline Preposition & 2 (two) & 1 (one) & - & 4 (four) & 1 (three) & - \\
\hline Citation & - & - & - & - & - & - \\
\hline Consistent use of word & - & - & - & - & - & - \\
\hline Sentence structure & 9 (nine) & 9 (nine) & 7 (seven) & 13 (thirteen) & 18 (eighteen) & 6 (six) \\
\hline Article & 3 (three) & 10 (ten) & 7 (seven) & 11 (eleven) & 21 (twenty one) & 2 (two) \\
\hline Misspelling & - & - & 1 (one) & - & - & - \\
\hline Possessive form & - & - & - & 1 (one) & - & - \\
\hline Gerund & - & - & - & - & - & - \\
\hline Subject & - & - & - & - & - & - \\
\hline Tenses & 3 (three) & 2 (two) & 7 (seven) & 5 (five) & 5 (five) & 3 (three) \\
\hline Passive voice & - & - & - & 1 (one) & - & - \\
\hline Word form & 1 (one) & 3 (three) & - & 1 (one) & - & - \\
\hline Pronoun & - & - & - & - & 2 (two) & - \\
\hline
\end{tabular}




\begin{tabular}{|c|c|c|c|c|c|c|}
\hline \multirow{2}{*}{$\begin{array}{c}\text { Categories of the } \\
\text { Grammatical Mistake }\end{array}$} & \multicolumn{6}{|c|}{ Student 3} \\
\hline & $1^{\text {st }}$ E-reflection & $2^{\text {nd }}$ E-reflection & $3^{\text {rd }}$ E-reflection & $4^{\text {th }}$ E-reflection & $5^{\text {th }}$ E-reflection & $\sigma^{\text {th }}$ E-reflection \\
\hline Punctuation & $2($ two $)$ & - & - & - & - & - \\
\hline Capitalization & - & - & - & - & - & - \\
\hline Plural form & 4 (four) & 1 (one) & 13 (thirteen) & 2 (two) & 2 (two) & - \\
\hline Word choice & 8 (eight) & 7 (seven) & 16 (sixteen) & $6(\operatorname{six})$ & $6(\operatorname{six})$ & 5 (five) \\
\hline Word order & 3 (three) & 2 (two) & 3 (three) & 1 (one) & 1 (one) & 1 (one) \\
\hline Preposition & 3 (three) & 4 (four) & 2 (two) & 4 (four) & 3 (three) & 3 (three) \\
\hline Citation & - & - & - & - & - & - \\
\hline Consistent use of word & - & - & - & - & - & - \\
\hline Sentence structure & 17 (seventeen) & $16($ sixteen $)$ & 11 (eleven) & 6 (six) & 5 (five) & 11 (eleven) \\
\hline Article & 5 (five) & 3 (three) & 11 (eleven) & 5 (five) & 4 (four) & 7 (seven) \\
\hline Misspelling & 1 (one) & - & - & - & - & - \\
\hline Possessive form & - & - & - & - & - & - \\
\hline Gerund & $2($ two $)$ & 2 (two) & 2 (two) & 4 (four) & 4 (four) & 3 (three) \\
\hline Subject & - & - & 3 (three) & - & - & - \\
\hline Tense & 34 (thirty four) & $\begin{array}{c}28 \text { (twenty } \\
\text { eight) }\end{array}$ & 18 (eighteen) & 12 (twelve) & 11 (eleven) & $\begin{array}{l}23 \text { (twenty } \\
\text { three) }\end{array}$ \\
\hline Passive voice & - & - & - & - & - & - \\
\hline Word form & - & - & - & - & - & - \\
\hline Pronoun & - & - & - & - & - & - \\
\hline
\end{tabular}




\section{Transcript Interview}

\section{Student 1}

Q : How do you feel about directive feedback from PETA course?

A: Kalo menurut aku sih feedback itu tidak sesuai dengan apa yang diharapkan, PETA kan harusnya konten sedangkan si dosen itu kan feedback-nya grammar. Buat aku kalau dari awal dikatakan yang akan dinilai itu grammar dia harus bilang dari awal biar ngak ada misunderstanding daripada... dan kadang- kadang yang dilakukan dia itu adalah mengubah konten yang mau disampaikan oleh si student. jadinya... karena kan tense ada berbagai macem yah. Jadi kita juga seandainya mungkin si student bilang A tapi karena dirubah jadinya bilang jadi B.

Translate:

According to me, feedback which is given from the lecturer is not as what we expected before. The feedback for PETA course should focus with content. However, the lecturer just focuses with the grammatical error. Then, it is should be stated in the first place.

\section{Coding:}

Facilitative feedback should be used for PETA course instead of directive feedback.

Directive feedback sometimes changes the student' intended meaning.

Q : Did you read carefully the directive feedback given by the lecturer?

A: Aku baca... aku baca. Biar aku tahu dan aku nulisnya ngak terlalu banyak ehm... ngak banyak bangetlah tetep ada beberapa cuma aku jadi lebih kelihatan, karenakan ada garis- garis merahnya.

Translate:

I read it in order I know the error one. Due to short reflection so it makes me easier to identify the feedback from lecturer

\section{Coding:}

Respondent read the given feedback.

Q : Did you learn from the given feedback? 
A: Satu structure yah? Penempatan kata. Kadang- kadang aku suka kebalik- balik gitu antara verb- nya sebelah mana. Terus ada penggunaan tenses gitu yang kadang- kadang harus dibenerin, sama membuat kalimat menjadi lebih efektif.

Translate:

First is structure. Sometimes, I am confused to put the right verb, use the right tenses and how to make effective sentences.

\section{Coding:}

Respondent notice some grammatical mistakes she made from reading the given feedback.

Q : How do you think directive feedback help you improve your writing skills?

A: Sebenernya kalo dari awal emang dibilang fokusnya ke grammar itu sih sangat membantu. Tapi kalau dari awal tujuan dia itu bukan buat grammar yaah jadi harusnya biar student itu tahu yang mana sih yang mau dikasih feedback. Maksudnya kayak ada satu mata kuliah dengan dosen tertentu dia bilang dia tidak melihat grammar tapi melihat konten jadi ketika melihat feedback kita tahu oh... ini masalah konten. Kalau masalah grammar dia akan bilang lagi diluar sebagai feedback oral bukan written yaa.ah..

Translate:

Actually, if the assessment of reflection also focuses in grammar, we will consider it. the criteria of feedback should be stated clearly whether focus on grammar or more in content.

\section{Coding:}

Respondent says that directive feedback is useful for improving grammatical competence. Respondent wants PETA course to define the objective of assessment from the first time.

\section{Student 2:}

Q: How do you feel about directive feedback from PETA course?

A: Jujur, directive feedback sangat membantu sekali. Miss Ine gak terlalu membatasi mahasiswa buat kamu harus kontennya seperti ini seperti ini, gak ngejudge seperti itu, tapi lebih ke grammar-nya and structure-nya. Jadi ngebantu sih. Seneng.

Translate: 
Honestly, directive feedback really helps me. The lecturer does not limit us about the content but more focus with the grammar and structure. So, I am happy

\section{Coding:}

She feels that directive feedback helps her as grammatically.

Q : Did you read carefully the directive feedback given by the lecturer?

A: Klo membaca secara detail sih enggak, tapi skimming, gak secara detail dibaca. Yang salah ini, harus gini. Dibaca tapi gak most of them yang directnya yang salah ini, harus gini. Maksudnya gak secara detail dibaca sih.

Translate:

I do not read detail but just skimming and focus with the mistakes

\section{Coding :}

She just skimmed the feedback given and not really detail in reading it.

\section{Q : Did you learn from the given feedback?}

A: Itu yg kadang buat dilemma maksudnya gini, kita kan learning dari miss Ine, dan juga gak learning dari feedback Miss Ine doang, kadang-kadang kita learning dari yang lain. Mungkin kita kadang masih ngulangin kesalahan. Tapi kadang juga enggak diulangin lagi soalnya udah realized yang salah ini yang salah ini.

Tapi entah dari feedbacknya miss Ine atau bukan aku gak nggeh. Yang penting tapi ngebantu banget.

Translate:

That's what makes me dilemma. Actually for grammar I learn from many sources not only from this feedback but it still helps me for sure

\section{Coding:}

She thinks that learning grammatical errors not only from given feedback but also from others. However, given feedback also helps her in learning those errors. 
Q : How do you think directive feedback help you improve your writing skills?

A : Bisa sih, refer ke pertanyaan yang sebelumnya. Ada beberapa pembelajaran dan salah satunya pembelajaran itu dari feedbacknya Miss Ine. Gak tau dari feedback-nya miss Ine aku harus gini atau ini. Ngulangin beberapa kesalahan tapi kan directive feedbacknya Miss Ine salah satu dari pembelajaran, masalahnya itu dari entah dari feedbacknya Miss Ine atau enggak.

\section{Translate:}

Yes, it could. I think my writing skill can improve not only from her feedback but also from other learning

\section{Coding:}

Directive feedback gives portion in helping her for improving writing.

\section{Student 3:}

Q: How do you feel about directive feedback from PETA course?

A: Bagus, dari itu aku sebagai mahasiswa sadar kalau dosen tersebut care sama kita. Tapi ada yang kurang dari feedback tersebut yaitu tidak adanya pengawasan dan beliau juga tidak memberi peringatan apabila ada mahasiswa yang mengulang kesalahan yang sama dalam refleksi selanjutnya.

Translate:

Good, from that feedback I just realized that lecturer cares with us. However, the weakness is lack of monitor from lecturer to remind students whether they will repeat the same mistake from the previous reflection.

Coding: directive feedback is good and it shows that the lecture care of the students.

Q: Did you read carefully the directive feedback given by the lecturer?

A: Kalau dibaca sih semua dibaca tapi sometimes dengan sepenuhnya dan aku sadar ternyata refleksi itu dari jadi saya tidak harus tulis "as you know,etc". jadi aku belajar tapi kadang setiap tugas itu dan refleksi banyak banget dan setiap refleksi di komentari jadi ada kecenderungan untuk malas membaca feedback tersebut. Aku juga tidak terlalu memperhatikan kesalahan grammarnya, aku lebih memperhatikan tata kalimatnya tahu dan aku juga sadar "ohh itu salah, seharusnya seperti ini"

Translate: 
I read all the feedback and it makes me realize some error parts that should be improved. I learn from that feedback however sometimes many feedbacks also discouraged me to read it.

\section{Coding:}

he reads the feedback but not in detail.

\section{Q: Apa kamu belajar dari directive feedback tersebut?}

A: Belajar, aku belajar dan 50\% yang aku apply. seperti beliau pernah bilang kalau "but" tidak boleh di awal tapi harusnya "yet" dan aku applied itu. Translate:

I learn and 50 percent I apply it.

\section{Coding:}

He learns $50 \%$ of the feedback.

Q:Menurut kamu, directive feedback itu bisa meningkatkan kemampuan menulis kamu tidak?

A: Membantu, tapi kalau di bilang karena itu saja tidak. Karena writing skill butuh praktek terus, mengetahui teorinya dan dapat feedback itu dapat meningkatkan writing skill. Dan apabila aku memperhatikan betul feedback tersebut, itu dapat sangat membantu untuk meningkatkan writing skill.

Translate:

It helps me in improving my writing. Yet, I also learn how to improve it by practicing and learning form others

\section{Coding:}

Directive feedback can help him to improve his writing skill. 